\title{
Analyzing the Economic Development-Driven Ecological Deficit in the EU-15 Countries: New Evidence From PSTR Approach
}

\section{Celil Aydin ( $\square$ caydin@bandirma.edu.tr )}

Bandirma Onyedi Eylul Universitesi https://orcid.org/0000-0002-0398-9884

\section{Ömer ESEN}

Namık Kemal Üniversitesi: Tekirdag Namik Kemal Universitesi

\section{Recai AYDIN}

Ankara Sosyal Bilimler Üniversitesi: Ankara Sosyal Bilimler Universitesi

\section{Research Article}

Keywords: Ecological Balance Sheet, Environmental Kuznets Curve (EKC), Panel Smooth Transition Regression (PSTR).

Posted Date: May 4th, 2021

DOI: https://doi.org/10.21203/rs.3.rs-425406/v1

License: (c) (i) This work is licensed under a Creative Commons Attribution 4.0 International License. Read Full License

Version of Record: A version of this preprint was published at Environmental Science and Pollution Research on October 9th, 2021. See the published version at https://doi.org/10.1007/s11356-021-167733. 


\title{
Analyzing the economic development-driven ecological deficit in the EU-15
} countries: New evidence from PSTR approach

\author{
Celil AYDIN ${ }^{*}$, Ömer ESEN ${ }^{2}$ and Recai AYDIN ${ }^{3}$
}

\begin{abstract}
This study empirically analyses the nonlinear impact of economic activities on ecological balance indicators that estimate the balance between economies' pressure on nature and the biologically productive resources areas affected by human activity and the earth's ecological carrying capacity. In measuring this balance, ecological balance sheet indicators are divided into four sub-components; cropland, forest area, fishing grounds and grazing land. The sample of the study consists of the EU-15 countries over the period 1995-2016. In order to render the study robust with respect to econometric issues like potential endogeneity bias, cross-country heterogeneity, time instability and nonlinearity, the study adopted panel smooth transition regression (PSTR) method. The empirical findings reveal that the economic activities carried out up to a certain threshold level do not force the ecological balance as nature can compensate for the resulting externalities, but beyond this threshold, waste accumulation and pollution exceed nature's capacity to absorb. Consequently, the results of the study are not in line with the expectation of the Environmental Kuznets Curve (EKC) hypothesis with inverted U-shaped curve, but indicate a need for implementation of active environmental policies for the improvement of the environment.
\end{abstract}

Keywords: Ecological Balance Sheet, Environmental Kuznets Curve (EKC), Panel Smooth Transition Regression (PSTR).

\section{Introduction}

Evidence regarding the interrelation between ecological and economic systems shows that economic activities and ecological changes have mutual effects on each other. In particular, disposal of the waste products of economic activities can be damaging to the ecology and interfere with the mutually supporting interactions within the ecological system. With the increasing pace and volume of economic activity ever increasing in volume, the burden on the ecological system is becoming correspondingly greater. Consumption of resources faster than rate of the renewal destroys the natural ecosystems on which the human life and biodiversity depend. As a result, many negative externalities contributing to

\footnotetext{
${ }^{1}$ Assoc. Prof., Department of Economics, Faculty of Economics and Administrative Sciences, Bandırma Onyedi Eylül University, 10200, Balıkesir, Turkey E-mail: caydin@bandirma.edu.tr

2 Assoc. Prof., Department of Economics, Faculty of Economics and Administrative Sciences, Namık Kemal University, 59030 Tekirdağ, Turkey E-mail: oesen@nku.edu.tr

${ }^{3}$ Prof. Dr., Department of Economics, Faculty of Political Sciences, Social Sciences University of Ankara, 06050

Ankara, Turkey E-mail: recai.aydin@asbu.edu.tr

* Corresponding Author
} 
global climate change such as decreasing forest areas, exhaustion of freshwater systems and increased carbon dioxide emissions are becoming increasingly damaging (Özsoy and Dinç, 2016). In recognition of this process, countries' goals should encompass both economic growth as traditionally measured and the sustainability of the process as well. Economic policies aiming at increasing welfare must therefore consider the economy and the environment as interdependent systems. In other words, it is crucial for countries, regions as well as any global initiative to understand that economic actions create pressure on ecosystems while they create economic growth and take into consideration this pressure before taking any policy decisions.

Human beings leave a mark on the earth while carrying out the production and consumption activities throughout their life. However, as they carry out these activities, they little notice the spillover effects on nature and the resulting pressure on the ecosystem, with the consequence that the ecological carrying capacity may be exceeded. Such overutilization in order that the biological capacity (bio-capacity) be preserved to create a balance between the resource requirements of current and future generations. In other words, to achieve sustainability, the natural resource consumption should not exceed the volume of the resources that the earth can regenerate them within a given time frame. The earth, where all living things continue their lives is inadequate to meet the needs due to the use of resources above the Biological Capacity (BC) - defined as the capacity of a geographical region to produce renewable natural resources. For this target, the Ecological Footprint (EF) measurements are seen as a vital measurement tool in the preparation of environmentally friendly policies required while ensuring economic development.

Following pioneering studies by Rees (1992), Rees and Wackernagel (1994) and Wackernagel and Rees (1996), the ecological footprint measures are being increasingly employed in studies applied to geographic regions, countries and specific productive activities. Given the available technology and resource management, the $\mathrm{EF}$, which measures the amount of the biologically productive soil and water areas (cropland, built-up land, forest land, grazing land, carbon uptake land and fishing grounds) required to reproduce the natural resources consumed by individuals, countries or activities in a given period and to absorb the waste creates, provides insight into how far the limits of the carrying capacity of the earth have been exceeded, rather than giving precise judgments. In this respect, the comparison of $\mathrm{EF}$ and $\mathrm{BC}$ indicates whether the earth can live within the limits of self-renewal.

An ecological deficit is observed when the EF of a country's (a particular person, society or economy) population exceeds the bio-capacity of that country's area. Under deficit conditions, natural resources are exhausted, environmental problems appear and it becomes difficult for a population to meet its needs. In contrast, an ecological reserve exists whenever a population's EC is below its region's biocapacity. 
The discussion on whether ecological resources are sufficient to attain sustainable economic growth began in the early 1970s. The Club of Rome's "Limits to Growth" approach, which posits that environmental quality will deteriorate with economic activity, has resonated in political and academic platforms and has become an effective argument. It is argued that the earth cannot provide the need for natural resources, clean, accessible water and fresh air if the population growth and economic development continue in this way (Meadows et al., 1972). These debates are a considerable warning in terms of drawing attention to the damage caused by economic activities on the earth's ecosystems and natural resources. This approach has also sparked the wick of a consensus on acting on a common platform against environmental issues.

However, the findings of many studies on potential environmental impacts of economic growth, such as Grossman and Krueger (1991, 1995), Beckerman (1992), Shafik and Bandyopadhyay (1992), Panayotou (1993), and Selden and Song (1994) in the early 1990s have led to doubts about the Limits of Growth paradigm, and new arguments have been put forward. This approach suggests that there is no positive or negative linear relationship between economic activities and environmental quality, in fact, environmental quality follows an inverted U-shaped pattern that initially falls and then rises as a function of per capita income. The basic notion of this approach which is also referred to as environmental Kuznets curve (henceforth EKC) hypothesis in the literature, is that as an economy develops, environmental deteriorations initially increase during the early development or industrialization stages and then tend to fall as they reach higher income per capita due to awareness of people and increased demand for a clean environment.

The fact that many natural disasters (such as hurricanes, floods, droughts, extreme cold and heat), which are thought to be caused by global climate changes in recent decades, and the effect of human -induced activities on environmental degradation led to re-thinking on the economic growth process and requestioning the EKC hypothesis. Some studies that find it wrong to have very optimistic expectations about the future of the world by considering the data that environmental degradation is decreasing in developed countries, draw attention to the global pollution, the situation of developing countries, and the pollutants that have irreversible effects.

Although the EKC hypothesis is interesting in terms of modeling environment-growth relationship or providing an alternative perspective on explaining the relationship, the EKC approach and its political propositions have started to be criticized in many respects by some theoretical and empirical research seeking answers to the question of how to achieve sustainable development. Criticisms of the EKC approach may generally be grouped under three headings.

The first point of these criticisms is that the typical inverted U-shaped EKC pattern implies that the environmental damage is not cumulative or its effects to the ecosystem can be reversed (Arrow et al., 1995; Tisdell, 2001, 2002; Bimonte, 2002; Tao et al., 2008; Czech, 2008; Caviglia-Harris et al., 2009; 
Fodha and Zaghdoud, 2010; Aydin et al., 2019; Esen et al., 2020). Some pollutants are cumulative, that is, they tend to accumulate in the environment (Tisdell, 2000). Furthermore, even if pollutants do not accumulate initially, they may begin to accumulate after a certain threshold capacity level is exceeded. Moreover, the direct impacts of some pollutants on the environment may be relatively small individually, but major environmental effects may occur when combined with others (Cooper, 2004; Solomon et al., 2016). Therefore, cumulative impacts may be difficult to predict and monitor due to insufficient environmental data, nature's reaction taking relatively long times, and complex ecological processes (Clark, 1994). Also, even if environmental investments increase as incomes rise, resources such as biodiversity may not be renewed to the extent that they are lost. In this case, biodiversity loss is, on any reasonable scale, essentially irreversible and monotonic as there is no threshold point as a function of income per capita (Tisdell, 1993; Asafu-Adjaye, 2003; Dietz and Adger, 2003; Simpson et al., 2005; Czech, 2008; Mills and Waite, 2009; Iritié, 2015; Ruiz-Agudelo et al., 2019).

The second consideration is that the EKC hypothesis, which is analyzed empirically, can only be valid for pollutants that have local and regional dimensions but not at the global level and their negative impact can be controlled with only limited effects on economic growth. Critics of the EKC often claim that these are the pollutants that involve local, direct and short-term costs, which have destructive effects which are limited to the environment of the area where they are being released (for example SOx, NOx, SPM, etc.). However, the EKC-type relation may not be meaningful for the accumulated stocks of waste, for pollutants involving relatively long-term social costs (eg. $\left.\mathrm{CO}_{2}\right)$ or for resource stocks (Holtz-Eakin and Selden, 1995; Arrow et al, 1995; Stern et al, 1996; Panayotou, 1997; Cavlovic et al., 2000; Lieb, 2003; York et al., 2003; Salvati and Zitti, 2008; Esen et al., 2020).

Thirdly, studies have been critical of the EKC evidence on the grounds that the functional specifications and econometric techniques employed could not capture actual shape of income-environmental quality relation (Stern, 1998; Romero-Ávila, 2008; Bagliani et al., 2008; Galeotti et al., 2009; Esteve and Tamarit, 2012; Chiu, 2012; Aydin et al., 2019; Esen et al., 2020). Majority of the studies cited above have usually adopted reduced-form models in which per capita income is based on a quadratic or cubic function. In these studies, the aim is to find the potential nonlinearity of the underlying function with strategies such as logarithmic transforms or cubic functions (He and Richard, 2010). However, this approach cannot have the flexibility to determine the true form of the relationship. Imposing a priori any parametric (eg. linear, nonlinear, quadratic or cubic) function or predetermining the types of models can lead to the selection of inappropriate models that may offer biased findings.

To sum up, this study aims to empirically examine the effect of income per capita on ecological deficit by using a large dataset for the EU-15 covering the period 1995-2016. The starting period of the study is determined by taking into account the White Paper "An energy policy for the European Union" outlining a common energy and environmental policy among the member states, adopted in 1995 (European Commission, 1995). To obtain a homogenous group of countries, each with a similar 
development status and policy approach, the sample involves the EU-15 countries that have taken common actions with regard to energy and environmental policy during the sample period. Failure to identify the appropriate country group in panel data analysis methods can have a seriously misleading effect on the findings and their policy implications, a problem this study avoids by employing data for countries following similar policies.

More specifically, this study makes two original contributions to ongoing debates in the literature regarding the analysis of the EKC hypothesis. Firstly, the inverse U-shaped pattern may be valid only for certain types of pollutants, especially atmospheric ones, while not being valid for the accumulated stocks of waste. It is also claimed that the EKC-type relation is likely to be more limited or weak where the feedback impacts of resource stocks including soil, forests and other ecosystems are meaningful (Arrow et al, 1995). To provide a more complete perspective, this study adopts both the total ecological deficit and its disaggregated components as new indicators of environmental degradation, which reveals the quantity of pressure on natural resource stocks (ecological assets) and where they originate, comparing the ecological footprint from human activities with the number of natural resources that can be produced in the same period, that is, with biological capacity. It is an important environmental indicator that determines to what extent human activities exceed basically two types of environmental limits, such as resource production and waste absorption (Wackernagel et al, 2004; Schaefer et al, 2006; Rugani et al, 2014). To contribute to the determination of the areas where the ecological deficit is concentrated and to better plan the efficient use of resources, the present study examines the ecological deficit both in total and in the sub-components, separated according to the major types of ecologically productive areas - grazing land, cropland, forest area and fishing grounds.

Secondly, in contrast to conventional parametric approaches, this study adopts the PSTR model as an innovative econometric technique that estimates the threshold level endogenously and allows a smooth change from one regime to another. Another advantage of this model is its ability to consider econometric issues such as potential endogeneity biases, nonlinearity, heterogeneity and time instability (Chiu, 2012; Wu et al, 2013). To the best of the authors' knowledge, this study is the first to adopt a PSTR model to the linkages between income and an ecological deficit. The motivation behind the choice of the PSTR model is based on the fact that contrary to the conventional econometric methods applied in previous studies, this empirical technique puts forward a strong solution to the EKC hypothesis and its empirical research, especially methodological criticisms.

To this end, the remainder of this study is organized as follows: Section 2 highlights the review of the literature on the environment-income relationship. Section 3 describes data, the methodology, and the empirical model. Section 4 provides and discusses the empirical findings, and finally Section 5 presents concluding remarks.

\section{Literature review}


Empirical findings in the literature testing the validity of the EKC differ and are quite mixed, depending on the types of pollutants selected, samples of countries/regions and time periods studied, the econometric techniques applied and other explanatory variables used in the model. Among these studies, Panayotou (1993), List and Gallet (1999), Bhattarai and Hammig (2001), Kahuthu (2006), Jalil and Mahmud (2009), Iwata et al. (2010), Fodha and Zaghdoud (2010), Nasir and Rehman (2011), Shahbaz et al. (2012), Saboori et al. (2012), Shahbaz et al. (2013), López-Menéndez et al. (2014), Lau et al. (2014), Shahbaz et al. (2014), Apergis and Ozturk (2015), Apergis (2016), Balaguer and Cantavella (2016), Jebli et al. (2016), Li et al. (2016), Wang et al. (2016), Ahmad et al. (2017), Solarin et al. (2017), Luo et al. (2017), Moutinho et al. (2017), and Dogan and Inglesi-Lotz (2020) have provided evidence of the validity of the EKC hypothesis and confirmed the inverted U-shape, whereas Agras and Chapman (1999), Koop and Tole (1999), Cole (2003), Richmond and Kaufmann (2006), Akbostanci et al. (2009), Caviglia-Harris et al. (2009), Luzzati and Orsini (2009), Ozturk and Acaravci (2010), Kearsley and Riddel (2010), He and Richard (2010), Pao et al. (2011), Azlina et al. (2014), Baek (2015), RobalinoLópez et al. (2015), Al-Mulali et al. (2015), Ozturk and Al-Mulali (2015), Katz (2015), Zoundi (2017), and Liu et al. (2017) have found either no evidence or weak evidence in support of an inverted U-shape. However, most of the aforementioned studies (and many others) in the literature on EKCs cited so far use either a specific pollution scale such as SOx, NOx, SPM, etc. or a global pollution scale such as $\mathrm{CO} 2$ as indicators of environmental quality. The problem with focusing on these particular pollutants is that they represent only a small part of total environmental issues (Al-Mulali et al., 2015a; Hervieux and Darné, 2015; Destek et al., 2018; Imamoglu, 2018).

In the literature, the association between income and environment is widely researched; however, the availability of studies related to an ecological deficit or its derivatives, which are considered to represent the overall human impact on the earth's ecosystem and the current state of stock resources relatively more accurately, remains limited. Among these studies, York et al. (2004) examined the cross-national variation in the ecological footprint (EF) per unit of income utilizing data on 139 countries in 1999. The findings reveal that economic development leads to greater environmental impacts and is unlikely to ensure sustainability. A study by Hervieux and Darné (2015) analysed the EKC hypothesis using conventional linear, quadratic and cubic functions, with standard and logarithmic specifications using time-series analysis for 7 Latin American countries over the period 1961-2007. Similarly, the finding that environmental degradation does not improve when income increases, emphasizes that the EKC is not valid for EF. Adopting the PSTR model, Aydin et al. (2019) examined the EKC hypothesis associating with EF for $26 \mathrm{EU}$ countries and found weak evidence in favor of an inverted U-shaped relationship between per capita income and EF. Similar findings were found in 141 countries by Bagliani et al (2008) utilizing ordinary least squares (OLS) and weighted least squares (WLS) analysis on linear, quadratic and cubic functions, in standard and logarithmic specifications, in 146 countries by CavigliaHarris et al. (2009), in 150 nations with populations over 1 million by Wang et al. (2013) using a spatial 
econometric approach, and in 94 countries by Paolo Miglietta et al. (2017) using the OLS on linear and nonlinear models.

In contrast, Aşıcı and Acar (2016) examines the economy-environment relationship using the panel data set of 150 countries' EF over the period 2004-2008. The findings confirm that there is an EKC type relationship between per capita income and the footprint of domestic production. Similar results were found in Qatar by Mrabet and Alsamara (2017) employing the autoregressive distributed lag (ARDL) model with the presence of unknown structural breaks, in the MENA countries by Charfeddine and Mrabet (2017) using panel cointegration and causality analysis, in 15 EU countries by Destek et al. (2018) adopting second generation panel data methods that consider possible cross- section dependence among countries, and in 11 newly industrialized countries by Destek and Sarkodie (2019) employing both augmented mean group (AMG) estimator and the heterogeneous panel causality method. Apart from these, Al-Mulali et al. (2015) found an EKC-type relation in upper middle- and high-income countries, but not in low- and lower middle-income countries, in a study of 93 countries using fixed effects and generalized moments (GMM) models, similar to Uddin et al. (2016) which provides evidence in favor of the EKC hypothesis in 10 countries of 22, but in others either absent or weak evidence.

Ecological Deficit measures are of great importance in terms of determining whether Earth's biological resources and ecosystem services are used within the boundary of self-renewal and creating a scientific basis for effective and feasible solutions to eliminate the imbalance caused by today's excessive consumption. To the best of our knowledge, however, in reviewing the literature, it is seen that there is no study in the framework of the EKC hypothesis that takes into account the ecological deficit variable as an indicator of environmental quality.

\section{Methodology}

This study aims to find out the relationship between ecological balance ${ }^{4}$ and economic growth. In order to achieve this goal, panel smooth transition regression model which was used by various studies including Bagliani et al. (2008), Al-mulali et al. (2015), Uddin et al. (2017) and Aydin et al. (2019) is employed. The model is explained in detail Aydin et al. (2019) and is presented in Equation (1);

$E B_{i, t}=\beta_{0}+\beta_{1}$ Growth $_{i, t}+\theta X_{i, t}+\varepsilon_{i, t}$

where $E B$ represents ecological balance; Growth is the GDP growth rate, $X$ represents other macroeconomic variables that might have an impact on ecological balance; $\varepsilon$ is the error term where $t=$ $1,2, \ldots, \mathrm{T}$ for time periods; and $\mathrm{i}=1,2,3 \ldots, \mathrm{N}$ for $\mathrm{N}$ countries.

The original model, Panel Threshold Regression (PTR) model, was introduced by Hansen (1999) as the first regression model which allows to determine regime-switching moments in the econometric model

\footnotetext{
${ }^{4}$ Ecological balance is the difference between the bio-capacity and ecological footprint of a region or country.
} 
analyzing the nonlinear relationship among the variables in panel data. Thus, it indicates on which time period the effect of the threshold variable on the dependent variable changes its direction and allows the researcher to compare the impact in regimes below or above the threshold. This situation causes the slope parameters to differ according to regime-switching mechanism that depends on the threshold variable. In the PTR approach, it is assumed that slope parameters vary suddenly and each regime differs with respect to the detected threshold value. However, it may not be possible to observe these sudden changes among the regimes in economic models (Güloğlu ve Nazlığlu, 2013: 11).

This approach classifies the countries in the panel data with respect to their per capita real GDP values and estimates a different set of parameters for each group in evaluating the relationship between ecological balance and per capita real GDP. As a result, this approach is built based on the assumption that there are certain differences between high per capita real GDP countries and low per capita real GDP countries. This assumption technically allows a developing country near the threshold to become suddenly a developed country. However, in reality, this switch does not happen in one period but happens over a longer period of time. Thus, estimated parameters change not instantly but smoothly. Therefore, the Panel Smooth Transition Regression (PTSR) approach which allows gradual transition of parameters from one regime to another is preferred in this study rather than the original PTR model. The method was introduced by Gonzalez, Terasvirta and Van Dijk (2005).

Non-linear relationship between ecological balance and economic growth is analyzed by using the transformed version of the model shown in Equation (1) into a two-regime fixed PTSR model shown in Equation (2):

$E B_{i, t}=\mu_{i}+\beta_{0} \operatorname{LnGDP_{i,t}}+\beta_{1} \operatorname{LnGDP} i, t * g\left(q_{i, t} ; \gamma, \theta\right)+\varepsilon_{i, t}$

where $E B$ represents logarithmic transformed value of per capita ecological balance; LnGDP represents logarithmic transformed value of per capita real GDP; $\varepsilon$ represents the error term; $t=1,2, \ldots, T$ represents time periods; and $\mathrm{i}=1,2,3 \ldots, \mathrm{N}$ represents countries included in the analysis. Coefficient $\mu_{i}$ is included to observe possible unit-specific fixed effects, and the variable $q_{i}$ is included to be used as a potential threshold variable. In Equation (2), the function of $g\left(q_{i, t} ; \gamma, \theta\right)$ is assumed to be logistic function and is included as a transition function, and explicitly is given in Equation (3):

$g\left(q_{i, t} ; \gamma, \theta\right)=\left[1+\exp \left(-\gamma\left(q_{i, t}-\theta\right)\right)\right]^{-1}$

In equation (3), the parameter of $\theta$ is a threshold parameter between two regimes which are represented by $g\left(q_{i, t} ; \gamma, \theta\right)=0$ and $g\left(q_{i, t} ; \gamma, \theta\right)=1$, and the parameter of $\gamma$ is the smoothness measure in the model with the aim of capturing the change in the value of the transition function (smoothness parameter). In other words, it reflects the nature of transition from one regime to another regime. The value of $\gamma$ approaching infinity $(\gamma \rightarrow \infty)$, as the smoothness parameter, indicates that transition from 0 to 1 does not happen instantly, unlike the PTR approach in which $\theta$ is the threshold parameter and the 
switching from one regime to another happens abruptly. In this situation, using the PTR approach will be proper to estimate the model. On the other hand, as the smoothness parameter approaches to zero $(\gamma \rightarrow 0)$ the transition function turns out to be a constant number and the estimation model is reduced to linear form. In this situation, panel within estimator as suggested by Fouquau et al. (2008; 287-288) will be more appropriate to estimate the model.

The transition function can take on values between 0 and 1 as it is a continuous function of the transition variable. In that regard, in equation (1), the regression coefficient becomes $\beta_{0}$ when the transition function takes the value of zero $\left(g\left(q_{i, t} ; \gamma, \theta\right)=0\right)$ and the regression coefficient becomes $\beta_{0}+\beta_{1}$ when the transition function takes the value of one $\left(g\left(q_{i, t} ; \gamma, \theta\right)=1\right)$. In other words, the regression coefficient becomes the weighted average of $\beta_{0}$ and $\beta_{1}$ when the resulting value of the transition function turns out to be between zero and one $\left(0<g\left(q_{i, t} ; \gamma, \theta\right)<1\right)$. Therefore, it is better to interpret only the signs of the coefficients in the PTSR model rather than interpret the coefficients directly (Fouquau et al., 2008; 287-288). In other words, the positive or negative impact on dependent variable caused by the independent variable can be estimated, hence allowing varying elasticities with respect to different time periods to be explained (Güloğlu ve Nazlığlu, 2013: 12).

PSTR model can result in two regimes as well as with more than two regimes. A version of PTSR model with more than two regimes is given in equation (3). The transition function with more than two regimes in PTSR model is given in equation (4) below.

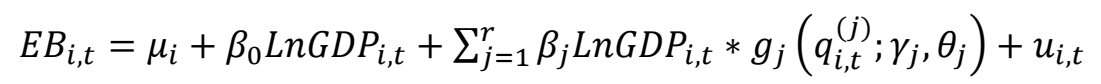

$g\left(q_{i, t} ; \gamma, \theta\right)=\left[1+\exp \left(-\gamma \prod_{j=1}^{m}\left(q_{i, t}-\theta_{j}\right)\right)\right]^{-1}, \gamma>0, c_{1} \leq c_{2} \leq \cdots \leq c_{m}$

Equation (5) provides the formula to calculate elasticity measure for the case in which the transition or threshold variable $(q)$ is different than the dependent variable $\left(q \neq \operatorname{LnGDP} P_{i, t}\right)$ in PSTR model with three or more regimes.

$e_{i, t}=\frac{\partial E B_{i, t}}{\partial \operatorname{LnGDP} P_{i, t}}=\beta_{0}+\sum_{j=1}^{r} \beta_{j} * g_{j}\left(q_{i, t}^{(j)} ; \gamma_{j}, \theta_{j}\right)$

Equation (6) provides the formula to calculate the elasticity measure for the case in which the transition or threshold variable $(q)$ is equal to the dependent variable $(q=\operatorname{LnGDP} i, t)$ in PSTR model with three or more regimes.

$e_{i, t}=\frac{\partial E B_{i, t}}{\partial \operatorname{LnGDP} P_{i, t}}=\beta_{0}+\sum_{j=1}^{r} \beta_{j} * g_{j}\left(q_{i, t}^{(j)} ; \gamma_{j}, \theta_{j}\right)+\sum_{j=1}^{r} \beta_{j} \frac{\partial g_{j}\left(q_{i, t}^{(j)} ; \gamma_{j}, \theta_{j}\right)}{\partial \operatorname{LnGDP} P_{i, t}} \operatorname{LnGDP_{i,t}}$

There are three steps in PSTR analysis. These are; testing for linearity, determination of appropriate number of regimes $(r)$ and model estimation (Fouquau et al., 2008; 287-288). Testing for linearity is achieved under the hypotheses $\gamma=0$ or $\beta_{0}=\beta_{1}=0$. However, the test statistics is not standard as 
there are some undefined parameters under the null hypotheses in both cases. As a result, a first degree Taylor expansion of $\gamma=0$ is employed. Using the standard F-test to test for linearity, linear model is employed in the case of non-rejection of the null hypothesis PSTR model is employed if the null hypothesis is rejected.

If the linear model is rejected, then appropriate number of regimes is found testing the null hypothesis of $r=r^{*}=1$ against the alternative hypothesis of $r=r^{*}+1$. If the null hypothesis cannot be rejected, then the existence of only one switching regime is considered. If the null hypothesis is rejected, then the new null hypothesis of $r=r^{*}+1$ is tested against the alternative hypothesis of $r=r^{*}+2$. This process is continued as long as the null hypothesis can be rejected as it was suggested by Fouquau et al. (2008; 287-288). Once the correct number of regimes are found, transformed model is estimated using the nonlinear least squares method (NLS) following subtracting the fixed effects of cross-sections from the time average values of the variables in the estimation stage (Gonzalez et al., 2005).

\section{Data, Empirical Results, and Implications}

\subsection{Data Specifications}

In this study, the non-linear relationship between ecological balance and economic growth as well as the non-linear relationship between economic growth and each of the equilibria that determine ecological balance in areas of Cropland, Fishing Grounds, Forest Products and Grazing Land are investigated in five separate models by using PSTR approach for $13 \mathrm{EU}$ countries for the period of 19952016. Following countries with available full data set are included in the study: Austria, Belgium, Denmark, France, Germany, Greece, Italy, Luxembourg, Netherlands, Portugal, Spain, Sweden and United Kingdom. Finland and Ireland are excluded from this study since their detailed sub-component data are not available.

In the models employed, each of the following variables--Cropland balance sheet $(C B S)$, Fishing grounds balance sheet $(F B S)$, Forest products balance sheet (FOBS), Grazing land balance sheet $(G B S)$ and Ecological balance sheet $(E B S)$--is employed as the dependent variable while the logarithm of per capita real GDP (LnGDPper) is included as the main independent variable of interest as an indicator of economic growth as well as the threshold variable for the models. In addition, other independent variables including the logarithm of energy consumption (LnEnergy), urbanization rate (Urbanization) and age dependency ratio (Dependency) are used as control variables in the model. Since it is assumed that all carbon uptake is considered within the biological capacity of other productive areas such as forest area, cropland, grazing land, forest land, and fishing grounds, there is no bio-capacity corresponding to the carbon footprint. Here, the inclusion of carbon bio-capacity in addition to forest land bio-capacity, in particular, may lead to double counting (Kitzes et al., 2008; Lin et al., 2016). Therefore, carbon bio-capacity individually is not included among the sub-components of the biocapacity accounts. Furthermore, the built-up land cannot practically produce an ecological balance, as 
construction available is physically built on former cropland. That is, it is assumed that the EF and BC of built-up land are equal (Toderoiu, 2010; Kori, 2013; Iha et al., 2015; Lin et al., 2016). Therefore, the model does not include built-up land balance accounts. Descriptive statistics of the variables included in the models are presented in Table 1. Detailed information on the databases where the variables of the study are obtained is given in Table 8 .

\section{[Table 1 here]}

As can be seen from Table 1, mean values of Cropland balance, Fishing grounds balance, Forest products balance, Grazing land balance and Ecological balance respectively are -0.238, 0.224, 0.417, 0.257 and -4.009 . In addition, correlation matrix of the dependent and independent variables is presented in Table 2 and it shows that there is a statistically significant negative correlation between per capita real GDP and Cropland balance, Grazing land balance and Ecological balance (-0.14, -0.47 and -0.50 , respectively) and statistically significant positive correlation between per capita real GDP and Fishing grounds balance $(0.11)$. On the other hand, the correlation between per capita real GDP and Forest products is very small and statistically insignificant.

\section{[Table 2 here]}

\subsection{Empirical Findings}

This study investigates non-linear relationships between ecological balance and economic growth, and between economic growth and ecological equilibrium in the areas of Cropland, Fishing Grounds, Forest Products and Grazing Land as well as dependency among the cross-sections (countries). ${ }^{5}$ It greatly affects the estimation results whether taking into consideration the dependency among the cross-sections making up the panel data or not (Breusch and Pagan, 1980; Pesaran, 2004). Therefore, existence of cross-sectional dependency in series and in the model should be tested prior to further analysis. This possibility should also be considered when selecting the unit roots in order to avoid misleading estimations. Thus, this study first analyzes the cross-sectional dependency using the $L M_{a d j}$ (Adjusted Lagrange Multiplier) test developed by Breusch-Pagan (1980) and further its deviation corrected by Pesaran et al. (2008). The results of the $L M_{a d j}$ test together with other comparable tests are provided in Table 3.

[Table 3 here]

As can be seen in Table 3, the null hypothesis that there is no cross-sectional dependency is strongly rejected based on the test results of the series related with variables used in the models. Therefore, it is

\footnotetext{
${ }^{5}$ Model 5 is set to explain the relationship between ecological balance and economic growth while Models 1,2,3 and 4 are set to explain the relationship between economic growth and balances in Cropland, Fishing Grounds, Forest Products and Grazing Land, respectively.
} 
concluded that there exists cross-sectional dependency in the series. This conclusion suggests that a shock in one of the countries affects others as well. As explained above, this result requires choosing appropriate test methods that take cross-sectional dependency into consideration when the methods are chosen for further stages of the analysis. As a result, in the later stages of this study, Moon and Perron's (2004) second generation panel unit root test, which takes the cross-sectional dependency and stationarity of series into consideration is used. The results of the Moon and Perron test are provided in Table 4. According to the results in Table 4, the null hypothesis claiming that the series has unit root is rejected for all series. This indicates that the series are stationary at level $(\mathrm{I}(0))$.

\section{[Table 4 here]}

Having established the stationarity of variables used in the models at level $(\mathrm{I}(0))$, the next step is to proceed with the first stage of PSTR analysis, that is testing the linear model against the non-linear model. The results of the Wald Test $(L M)$, Fisher Tests $\left(L M_{F}\right)$ and LRT Tests $(L R T)$ which are used to test linearity in the models and also to determine the number of transition function are shown in Table 5.

[Table 5 here]

As can be seen in Table 5, the null hypothesis is rejected at the 1\% significance level in models 1,4 and 5, and rejected at the 5\% significance level in models 2 and 3 according to the $L M, L M_{F}$ and $L R T$ test results. Thus, the alternative hypothesis which suggests that there is at least one non-linear threshold effect in each model is accepted. Hence, it can be concluded that it is not appropriate to use linear models in investigating the impact of per capita real GDP on Cropland, Fishing Grounds, Forest Products and Grazing Land equilibriums and ecological balance. Once it is determined that the linear model is not appropriate for all models for further analysis, the next step is to determine the appropriate number of regimes. For that purpose, $L M, L M_{F}$ and $L R T$ tests are repeated for all models and the results are shown in Table 6.

\section{[Table 6 here]}

As can be seen in Table 6, the null hypothesis that the model has one threshold effect cannot be rejected for all models. Thus, it is concluded that all models have one threshold effect and the model can be estimated using the PSTR approach with two regimes. In the next step, both non-linear relationships between ecological balance and economic growth, and non-linear relationship between economic growth and the equilibrium in each of the areas of Cropland, Fishing Grounds, Forest Products and Grazing Land which determine the ecological balance are estimated using the PSRT method with two regimes. The results appear in Table 7.

As it can be seen in Table 7, the smoothing parameter $(\gamma)$ turns out to be very small for each model (3.570, 16.186, 8.596, 3.809 and 26.594 respectively). The relatively small value for $\gamma$ indicates that 
switching from one regime to another is not sudden but rather smooth in the relation between per capita real GDP and each equilibrium situation. This situation is demonstrated in the Figures 1 in the appendix for each model.

\section{[Table 7 here]}

Also, as can be seen in Table 7, the threshold values for per capita real GDP for model 1 is found to be $\$ 32,565.22(\theta=10.391)$; for model 2 , it is $\$ 33,389.61(\theta=10.416)$; for model 3 , it is $\$ 53,103.60$ $(\theta=10.880)$; for model 4 , it is $\$ 89,859.26(\theta=11.406)$ and for model 5 it is $\$ 61,697.58(\theta=11.030)$. The coefficient estimated for per capita real GDP $\left(\beta_{0}\right)$ in the first regime where per capita real GDP is below the threshold value is statistically significant and negative (-0.454) at the 5\% significance level for model 1 ; it is statistically significant and negative $(-0.013)$ at the $10 \%$ significance level for model 3 ; it is statistically significant and negative (-0.004) at the 5\% significance level for model 4 and is statistically significant and negative (-1.259) at the $1 \%$ level for model 5 . The coefficient estimated for per capita real GDP $\left(\beta_{0}\right)$ is found to be not statistically significant for model 2 . The coefficient estimated for per capita real GDP $\left(\beta_{0}+\beta_{1}\right)$ in the second regime, where per capita real GDP is below the threshold value, is statistically significant and positive (0.053) at the $10 \%$ significance level for model 1 ; it is statistically significant and positive (0.023) at the 5\% level for model 4 and statistically significant and positive (4.915) at the $10 \%$ level for model 5. The coefficient estimated for per capita real GDP $\left(\beta_{0}+\beta_{1}\right)$ is found to be not statistically significant for model 2 and 3 .

Further interpretation of the PSTR model is as follows: In the first model, where the relationship between Cropland balance and economic growth is estimated, it is found that an increase in economic growth has a negative impact on Cropland balance when the per capita real GDP is below $\$ 32,565.22$ while an increase in economic growth has positive impact on Cropland balance when the per capita real GDP is above $\$ 32,565$.22. In model 3 where the relationship between the Forest Products balance and economic growth is investigated, it is found that increase in economic growth has negative impact on Forest Products balance when the per capita real GDP is below $\$ 53,103.60$ while there is no statistically significant relation detected between economic growth and Forest Products balance when the per capita real GDP is above $\$ 53,103.60$. In model 4 where the relationship between the Grazing Land balance and economic growth is estimated, it is found that increase in economic growth has a negative impact on Grazing Land balance when the per capita real GDP is below $\$ 89,859.26$ while an increase in economic growth has a positive impact on Grazing Land balance when the per capita real GDP is above $\$ 89,859.26$. In model 5 where the relationship between Ecological balance and economic growth is estimated, it is found that increase in economic growth has negative impact on Ecological balance when the per capita real GDP is below $\$ 61,697.58$ while an increase in economic growth has a positive impact on Ecological balance when the per capita real GDP is above $\$ 61,697.58$. However, PSTR model findings indicate no significant relation between economic growth and Fishing Grounds balance. In 
addition, when the coefficients are analyzed in terms of their magnitude, the impact of economic growth on Ecological balance is greater than the impact of economic growth on Cropland balance, Fishing Grounds balance, Forest Products balance and Grazing Land balance.

The estimated coefficients for control variables that may possibly affect the equilibrium situation in each model such as age dependency ratio, urbanization ratio and energy consumption are given in Table 7. In model 1 where the relationship between the Cropland balance and economic growth is estimated, it is found that an increase in the urbanization ratio and energy consumption has a positive impact on Cropland balance (coefficients are 0,038 and 0,019, respectively) when the per capita real GDP is below $\$ 32,565.22$ while it has a negative impact on Cropland balance (coefficients are $-0,029$ and $-0,016$ respectively) when the per capita real GDP is above $\$ 32,565.22$. Age dependency ratio is found to be not significant on Cropland balance.

In model 2, in which the relationship between Fishing Grounds balance and economic growth is estimated, it is found that an increase in age dependency ratio and energy consumption has a positive impact on Fishing Grounds balance (coefficients are 0.011 and 0.004 respectively) while an increase in urbanization ratio has negative impact on Fishing Grounds balance $(-0,006)$ when the per capita real GDP is below $\$ 33,389.61$. On the other hand, when the per capita real GDP is above $\$ 33,389.61$, an increase in age dependency ratio has positive impact on Fishing Grounds balance $(0,001)$ while an increase in urbanization rate has negative impact on Fishing Grounds balance $(-0,001)$. Energy Consumption is found to be not significant on Fishing Grounds balance when the per capita real GDP is above $\$ 33,389.61$.

In model 3 where the relationship between Forest Products balance and economic growth is estimated, it is found that an increase in age dependency ratio has positive impact on Forest Products balance $(0,020)$ while there is no significant relationship detected between energy consumption and Forest Products balance or between urbanization ratio and Forest Products balance when the per capita real GDP is below $\$ 53,103.60$. Furthermore, when the per capita real GDP is above $\$ 53,103.60$, none of the control variables are found to be significant on Forest Products balance.

In model 4 where the relationship between Grazing Land balance and economic growth is estimated, it is found that an increase in age dependency ratio has positive impact on Grazing Land balance $(0,015)$ while increase in urbanization ratio has negative impact on Grazing Land balance $(-0,011)$ when the per capita real GDP is below $\$ 89,859.26$. On the other hand, when the per capita real GDP is above $\$ 89,859.26$, an increase in age dependency ratio has negative impact on Grazing Land balance $(-0,043)$ while an increase in urbanization rate has positive impact on Grazing Land balance $(0,013)$. Energy Consumption is found to be not significant on Grazing Land balance in both regimes.

In model 5 where the relationship between Ecological balance and economic growth is estimated, it is found that an increase in age dependency ratio has a positive impact on Ecological balance $(0,146)$ when 
the per capita real GDP is below $\$ 61,697.58$. However, when the per capita real GDP is above $\$ 61,697.58$, an increase in age dependency ratio has negative impact on Ecological balance $(-0,629)$ Energy Consumption and urbanization rate are found to be not significant on Ecological balance in both regimes.

\section{Conclusion}

This study provides new empirical evidence on the ecological effects of economic activities in terms of ecological balance calculations, taking account of the main criticisms of the EKC hypothesis and its policy implications in the literature. The study empirically investigates effects of per capita income on the ecological balance sheet—namely, total ecological balance, cropland balance, grazing land balance, forest area balance, and fishing grounds balance- and analyzes whether the relationship can exhibit the inverted U-curve of the EKC path. The sample of this study consists of $13 \mathrm{EU}$ countries observed for the period 1995-2016. To examine the impact of per capita real GDP on ecological balance sheets, this study uses the Panel STR approach that can endogenously estimate the turning point while also allowing parameters to change smoothly from one regime to another.

The empirical findings confirm that there is a non-linear link between per capita income and total ecological balance and its main components; cropland balance, grazing land balance, forest area balance, and fishing grounds balance. However, this study found no evidence to support the existence of the inverted U-shape EKC pattern for both total ecological balance sheet and its sub-components.

The results from the PSTR model indicate that as the amount of goods and services produced per capita increases, the process initially improves the total ecological balance, cropland balance and grazing land balance and after above per capita income levels of approximately $\$ 61.697, \$ 32.565$ and $\$ 89.859$, respectively, environmental degradation occurs smoothly. These findings indicate that above a certain threshold level, nature is strongly polluted by human activities and cannot absorb this pollution at this rate, which exceeds its regenerative capacity. In other words, a higher production of goods and services results in a higher ecological erosion for grazing land, cropland, and total land.

Secondly, the findings obtained for forest area balance and fishing grounds balance differ. According to these results, there is a sustainable structure for the forest area up to the per capita income threshold of $\$ 53,103$ but this statistical relationship deteriorates once this threshold level is surpassed, that is, the results become statistically insignificant. In addition, the effects of per capita income on fishing grounds balance are statistically insignificant both below and above the threshold of $\$ 33,389$. The insignificance of the relationship between per capita real GDP and fishing grounds balance may be due to the expansion of aquaculture alongside traditional fishing activities in the last few decades. It is known that the importance of aquaculture increases in meeting the protein needs of the rapidly increasing population worldwide, as natural stocks gradually decrease. Based on FAO's (2020) data, as of 2018, aquaculture supplies about $46 \%$ ( 82.1 million tons) of total seafood production and about $52 \%$ of fish for human 
consumption. Despite these findings, it is not clear that aquaculture is beneficial on balance. It is argued that aquaculture, which has made critical contributions to protection of biodiversity and food security as well as limiting overfishing, has a number of detrimental effects on the environment. Therefore, changing a negative activity such as overfishing with a solution like aquaculture that could potentially cause a different range of problems might not be the right step. The transition from traditional fishing to aquaculture may have an unexpected impact on the nexus between per capita real GDP and fishing grounds variables.

Finally, the findings of this study suggest that, for countries with per capita real GDP levels higher than the critical threshold, governments should consider limiting the ecologically damaging economic activities or imposing regulations to modify how they are conducted in order to reduce the ecological damage.

Acknowledgements The authors would like to thank the editor and two anonymous reviewers for their helpful comments on an earlier draft of this study.

Author's contributions Ömer Esen and Recai Aydin contributed to the conception of the study. Celil Aydin and Recai Aydin performed the experiment and wrote the manuscript. Celil Aydin and Ömer Esen performed the analysis with constructive discussions. All authors read and approved the final manuscript.

Funding Not applicable.

Availability of data and materials The data sets supporting the results of this article are included within the article and its additional files.

\section{Declarations}

Ethics approval and consent to participate Not applicable.

Consent for publication Written informed consent for publication was obtained from all participants.

Conflict of interests The authors declare that they have no competing interests.

\section{References}

Agras, J., \& Chapman, D. (1999). A dynamic approach to the Environmental Kuznets Curve hypothesis. Ecological Economics, 28(2), 267-277. https://doi.org/10.1016/S0921-8009(98)00040-8

Ahmad, N., Du, L., Lu, J., Wang, J., Li, H. Z., \& Hashmi, M. Z. (2017). Modelling the $\mathrm{CO}_{2}$ emissions and economic growth in Croatia: Is there any environmental Kuznets curve? Energy, 123, 164-172. https://doi.org/10.1016/j.energy.2016.12.106 
Al-Mulali, U., Weng-Wai, C., Sheau-Ting, L., \& Mohammed, A. H. (2015). Investigating the environmental Kuznets curve (EKC) hypothesis by utilizing the ecological footprint as an indicator of environmental $\quad$ degradation. Ecological 315-323. https://doi.org/10.1016/j.ecolind.2014.08.029

Akbostanci, E., Turut-Asik, S., \& Tunc, G. I. (2009). The relationship between income and environment in Turkey: is there an environmental Kuznets curve?. Energy policy, 37(3), 861-867. https://doi.org/10.1016/j.enpol.2008.09.088

Apergis, N. (2016). Environmental Kuznets curves: New evidence on both panel and country-level CO2 emissions. Energy Economics, 54, 263-271.

Apergis, N., \& Ozturk, I. (2015). Testing environmental Kuznets curve hypothesis in Asian countries. Ecological Indicators, 52, 16-22. https://doi.org/10.1016/j.ecolind.2014.11.026

Arrow, K., Bolin, B., Costanza, R., Dasgupta, P., Folke, C., Holling, C. S., ... \& Pimentel, D. (1995). Economic growth, carrying capacity, and the environment. Ecological economics, 15(2), 91-95. https://doi.org/10.1016/0921-8009(95)00059-3

Asafu-Adjaye, J. (2003). Biodiversity loss and economic growth: a cross-country analysis. Contemporary Economic Policy, 21(2), 173-185. https://doi.org/10.1093/cep/byg003

Aşıcı, A. A., \& Acar, S. (2016). Does income growth relocate ecological footprint?. Ecological Indicators, 61, 707-714. https://doi.org/10.1016/j.ecolind.2015.10.022

Aydin, C., Esen, Ö., \& Aydin, R. (2019). Is the ecological footprint related to the Kuznets curve a real process or rationalizing the ecological consequences of the affluence? Evidence from PSTR approach. Ecological indicators, 98, 543-555. https://doi.org/10.1016/j.ecolind.2018.11.034

Azlina, A. A., Law, S. H., \& Mustapha, N. H. N. (2014). Dynamic linkages among transport energy consumption, income and $\mathrm{CO}_{2}$ emission in Malaysia. Energy Policy, 73, 598-606. https://doi.org/10.1016/j.enpol.2014.05.046

Baek, J. (2015). Environmental Kuznets curve for $\mathrm{CO}_{2}$ emissions: the case of Arctic countries. Energy Economics, 50, 13-17. https://doi.org/10.1016/j.eneco.2015.04.010

Bagliani, M., Bravo, G., \& Dalmazzone, S. (2008). A consumption-based approach to environmental Kuznets curves using the ecological footprint indicator. Ecological Economics, 65(3), 650-661.

Balaguer, J., \& Cantavella, M. (2016). Estimating the environmental Kuznets curve for Spain by considering fuel oil prices (1874-2011). Ecological Indicators, 60, 853-859. https://doi.org/10.1016/j.ecolind.2015.08.006

Beckerman, W. (1992). Economic growth and the environment: Whose growth? Whose environment?. World development, 20(4), 481-496. 
Beckerman, W. (1992). Economic growth and the environment: Whose growth? Whose environment?. World development, 20(4), 481-496. https://doi.org/10.1016/0305-750X(92)90038W

Bhattarai, M., \& Hammig, M. (2001). Institutions and the environmental Kuznets curve for deforestation: a crosscountry analysis for Latin America, Africa and Asia. World development, 29(6), 995-1010. https://doi.org/10.1016/S0305-750X(01)00019-5

Bimonte, S. (2002). Information access, income distribution, and the Environmental Kuznets Curve. Ecological economics, 41(1), 145-156. https://doi.org/10.1016/S0921-8009(02)00022-8

Breusch, T.S., Pagan, A.R., 1980. The Lagrange multiplier test and its applications to model specification in econometrics. Rev. Econ. Stud. 47 (1), 239-253.

Caviglia-Harris, J. L., Chambers, D., \& Kahn, J. R. (2009). Taking the "U" out of Kuznets: A comprehensive analysis of the EKC and environmental degradation. Ecological Economics, 68(4), 1149-1159.

Cavlovic, T. A., Baker, K. H., Berrens, R. P., \& Gawande, K. (2000). A meta-analysis of environmental Kuznets curve studies. Agricultural and Resource Economics Review, 29(1), 32-42.

Charfeddine, L., \& Mrabet, Z. (2017). The impact of economic development and social-political factors on ecological footprint: A panel data analysis for 15 MENA countries. Renewable and Sustainable Energy Reviews, 76, 138-154.

Chiu, Y. B. (2012). Deforestation and the environmental Kuznets curve in developing countries: A panel smooth transition regression approach. Canadian Journal of Agricultural Economics/Revue canadienne d'agroeconomie, 60(2), 177-194.

Clark, R. (1994). Cumulative effects assessment: a tool for sustainable development. Impact Assessment, 12(3), 319-331. https://doi.org/10.1080/07349165.1994.9725869

Cole, M. A. (2003). Development, trade, and the environment: how robust is the Environmental Kuznets Curve?. Environment and Development Economics, 8(4), 557-580. https://doi.org/10.1017/S1355770X0300305

Cooper, L. M. (2004). Guidelines for Cumulative Effects Assessment in SEA of Plans: EPMG Occasional Paper 04/LMC/CEA. London: Imperial College London.

Czech, B. (2008). Prospects for reconciling the conflict between economic growth and biodiversity conservation with technological progress. Conservation Biology, 22(6), 1389-1398.

Destek, M. A., \& Sarkodie, S. A. (2019). Investigation of environmental Kuznets curve for ecological footprint: the role of energy and financial development. Science of the Total Environment, 650, 24832489. 
Destek, M. A., Ulucak, R., \& Dogan, E. (2018). Analyzing the environmental Kuznets curve for the EU countries: the role of ecological footprint. Environmental Science and Pollution Research, 25(29), 29387-29396.

Dietz, S., \& Adger, W. N. (2003). Economic growth, biodiversity loss and conservation effort. Journal of environmental management, 68(1), 23-35.

Dogan, E., \& Inglesi-Lotz, R. (2020). The impact of economic structure to the environmental Kuznets curve (EKC) hypothesis: evidence from European countries. Environmental Science and Pollution Research, 27(11), 12717-12724. https://doi.org/10.1007/s11356-020-07878-2

Esen, Ö., Yıldırım, D. Ç., \& Yıldırım, S. (2020). Threshold effects of economic growth on water stress in the Eurozone. Environmental Science and Pollution Research, 27, 31427-31438. https://doi.org/10.1007/s11356-020-09383-y

Esteve, V., \& Tamarit, C. (2012). Threshold cointegration and nonlinear adjustment between CO2 and income: the environmental Kuznets curve in Spain, 1857-2007. Energy Economics, 34(6), 21482156.

European Commission (1995). White paper: An energy policy for the European Union. Brussels: EU Law and Publications.

FAO (2020). The State of World Fisheries and Aquaculture 2020. Rome: Food and Agriculture Organization of the United Nations. (Accessed on 19.02.2021), http://www.fao.org/3/ca9229en/CA9229EN.pdf

Fodha, M., \& Zaghdoud, O. (2010). Economic growth and pollutant emissions in Tunisia: an empirical analysis of the environmental Kuznets curve. Energy Policy,38(2), 1150-1156. $\underline{\text { https://doi.org/10.1016/j.enpol.2009.11.002 }}$

Fouquau, J., Hurlin, C., Rabaud, I., 2008. The Feldstein-Horioka puzzle: a panel smooth transition regression approach. Econ. Model. 25, 284-299.

Galeotti, M., Manera, M., \& Lanza, A. (2009). On the robustness of robustness checks of the environmental Kuznets curve hypothesis. Environmental and Resource Economics, 42(4), 551-574. https://doi.org/10.1007/s10640-008-9224-x

González, A., Teräsvirta, T., \& van Dijk, D. (2005). Panel smooth transition regression models. SSE/EFI Working Paper Series in Economics and Finance, WP No. 604.

Grossman, G. M., \& Krueger, A. B. (1991). Environmental Impacts of a North American Free Trade Agreement. NBER Working Papers, WP. No: 3914.

Grossman, G. M., \& Krueger, A. B. (1995). Economic Growth and the Environment. The Quarterly Journal of Economics, 110(2), 353-377. https://doi.org/10.2307/2118443 
Güloğlu, B., Nazlıoğlu, Ş., 2013. Enflasyonun Tarımsal Fiyatlar Üzerindeki Etkileri: Panel Yumuşak Geçiş Regresyon Analizi. Siyaset, Ekonomi ve Yönetim Dergisi 1 (1), 1-20.

He, J., \& Richard, P. (2010). Environmental Kuznets curve for CO2 in Canada. Ecological Economics, 69(5), 1083-1093.

Hervieux, M. S., \& Darné, O. (2015). Environmental Kuznets curve and ecological footprint: a time series analysis. Economics Bulletin, 35(1), 814-826.

Holtz-Eakin, D., \& Selden, T. (1995). Stoking the fires? CO2 emissions and economic growth. Journal of Public Economics, 57(1), 85-101. https://doi.org/10.1016/0047-2727(94)01449-X

Iha, K., Poblete, P., Panda, D., \& Sebastian, W. (2015). A Footprint Analysis of ASEAN: Ensuring Sustainable Development in an Increasingly Resource Constrained World. Asian Biotechnology \& Development Review, 17(2), 57-67.

Imamoglu, H. (2018). Is the informal economic activity a determinant of environmental quality?. Environmental Science and Pollution Research, 25(29), 29078-29088.

Iritié, B. G. J. J. (2015). Economic growth and biodiversity: An overview. Conservation policies in Africa. Journal of Sustainable Development, 8(2), 196-208.

Iwata, H., Okada, K., \& Samreth, S. (2010). Empirical study on the environmental Kuznets curve for $\mathrm{CO}_{2}$ in France: the role of nuclear energy. Energy Policy, 38(8), 4057-4063. https://doi.org/10.1016/j.enpol.2010.03.031

Jalil, A., \& Mahmud, S. F. (2009). Environment Kuznets curve for $\mathrm{CO}_{2}$ emissions: a cointegration analysis for China. Energy Policy, 37(12), 5167-5172. https://doi.org/10.1016/j.enpol.2009.07.044

Jebli, M. B., Youssef, S. B., \& Ozturk, I. (2016). Testing environmental Kuznets curve hypothesis: The role of renewable and non-renewable energy consumption and trade in OECD countries. Ecological Indicators, 60, 824-831. https://doi.org/10.1016/j.ecolind.2015.08.031

Kahuthu, A. (2006). Economic growth and environmental degradation in a global context. Environment, Development and Sustainability, 8(1), 55-68. https://doi.org/10.1007/s10668-005-0785-3

Katz, D. (2015). Water use and economic growth: reconsidering the Environmental Kuznets Curve $\begin{array}{llll}\text { relationship. Journal } \quad \text { of } \quad \text { Cleaner } & \text { Production, 88, }\end{array}$ https://doi.org/10.1016/j.jclepro.2014.08.017

Kearsley, A., \& Riddel, M. (2010). A further inquiry into the Pollution Haven Hypothesis and the Environmental Kuznets Curve. Ecological Economics, 69(4), 905-919. https://doi.org/10.1016/j.ecolecon.2009.11.014

Kitzes, J., Galli, A., Rizk, S. M., Reed, A., \& Wackernagel, M. (2008). Guidebook to the national footprint accounts. Oakland: Global Footprint Network. 
Li, T., Wang, Y., \& Zhao, D. (2016). Environmental Kuznets curve in China: new evidence from dynamic panel analysis. Energy Policy, 91, 138-147. https://doi.org/10.1016/j.enpol.2016.01.002

Lieb, C. M. (2003). The environmental Kuznets curve: a survey of the empirical evidence and of possible causes (No. 391). Discussion paper series, No. 391. Heidelberg: University of Heidelberg, Department of Economics.

Lin, D., Hanscom, L., Martindill, J., Borucke, M., Cohen, L., Galli, A., Lazarus, E., Zokai, G., Iha, K., Eaton, D., \& Wackernagel, M. (2016). Working Guidebook to the National footprint accounts. Oakland: Global Footprint Network.

List, J. A., \& Gallet, C. A. (1999). The environmental Kuznets curve: does one size fit all? Ecological economics, 31(3), 409-423. https://doi.org/10.1016/S0921-8009(99)00064-6

Liu, X., Zhang, S., \& Bae, J. (2017). The impact of renewable energy and agriculture on carbon dioxide emissions: Investigating the environmental Kuznets curve in four selected ASEAN countries. Journal
of
Cleaner
Production, 164,
1239-1247.

\section{https://doi.org/10.1016/j.jclepro.2017.07.086}

Luo, G., Weng, J. H., Zhang, Q., \& Hao, Y. (2017). A reexamination of the existence of environmental Kuznets curve for $\mathrm{CO}_{2}$ emissions: evidence from G20 countries. Natural Hazards, 85(2), 1023-1042. https://doi.org/10.1007/s11069-016-2618-0

Luzzati, T., \& Orsini, M. (2009). Investigating the energy-environmental Kuznets curve. Energy, 34(3), 291-300. https://doi.org/10.1016/j.energy.2008.07.006

Meadows, D. H., Meadows, D. L., Randers, J., \& Behrens, W. W. (1972). The limits to growth. New York: Universe Books.

Mills, J. H., \& Waite, T. A. (2009). Economic prosperity, biodiversity conservation, and the environmental Kuznets curve. Ecological Economics, 68(7), 2087-2095.

Moon, H.R., Perron, B., 2004. Testing for a unit root in panels with dynamic factors. J. Econometrics $122(1), 81-126$.

Moutinho, V., Varum, C., \& Madaleno, M. (2017). How economic growth affects emissions? An investigation of the environmental Kuznets curve in Portuguese and Spanish economic activity sectors. Energy Policy, 106, 326-344. https://doi.org/10.1016/j.enpol.2017.03.069

Mrabet, Z., \& Alsamara, M. (2017). Testing the Kuznets Curve hypothesis for Qatar: A comparison between carbon dioxide and ecological footprint. Renewable and Sustainable Energy Reviews, 70, 1366-1375. 
Nasir, M., \& Rehman, F. U. (2011). Environmental Kuznets curve for carbon emissions in Pakistan: an empirical investigation. Energy Policy, 39(3), 1857-1864. https://doi.org/10.1016/j.enpol.2011.01.025

Özsoy, C. E., \& Dinç, A. (2016). Sustainable Development and Ecological Footprint. Finans Politik \& Ekonomik Yorumlar, 53(619), 35.

Ozturk, I., \& Acaravci, A. (2010). $\mathrm{CO}_{2}$ emissions, energy consumption and economic growth in

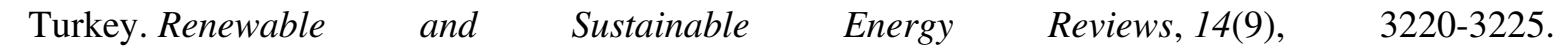
https://doi.org/10.1016/j.rser.2010.07.005

Ozturk, I., \& Al-Mulali, U. (2015). Investigating the validity of the environmental Kuznets curve hypothesis in $\quad$ Cambodia. Ecological 324-330. https://doi.org/10.1016/j.ecolind.2015.05.018

Panayotou, T. (1993). Empirical tests and policy analysis of environmental degradation at different stages of economic development. WP. No: 238, Technology and Employment Programme, International Labour Organization, Geneva.

Panayotou, T. (1997). Demystifying the environmental Kuznets curve: turning a black box into a policy tool. Environment and development economics, 465-484.

Pao, H. T., Yu, H. C., \& Yang, Y. H. (2011). Modeling the $\mathrm{CO}_{2}$ emissions, energy use, and economic growth in Russia. Energy, 36(8), 5094-5100. https://doi.org/10.1016/j.energy.2011.06.004

Paolo Miglietta, P., De Leo, F., \& Toma, P. (2017). Environmental Kuznets curve and the water footprint: An empirical analysis. Water and Environment Journal, 31(1), 20-30.

Pesaran, 2004. M.H. Pesaran General Diagnostic Tests for Cross Section Dependence in Panels. CESifo Working No. 1229.

Pesaran, M.H., Ullah, A., Yamagata, T., 2008. A bias-adjusted LM test of error crosssection independence. Econometrics J. 11 (1), 105-127.

Rees, W. E. (1992). Ecological footprints and appropriated carrying capacity: what urban economics leaves out. Environment and 121-130. https://doi.org/10.1177/095624789200400212

Rees, W. E., \& Wackernagel, M. (1994). Ecological footprints and appropriated carrying capacity: measuring the natural capital requirements of the human economy. In: Investing in Natural Capital: The Ecological Economics Approach to Sustainability, A.-M. Jansson, M. Hammer, C. Folke, R. Costanza (Eds.), pp. 362-390, Washington, DC: Island Press. 
Richmond, A. K., \& Kaufmann, R. K. (2006). Is there a turning point in the relationship between income and energy use and/or carbon emissions?. Ecological economics, 56(2), 176-189. https://doi.org/10.1016/j.ecolecon.2005.01.011

Robalino-López, A., Mena-Nieto, Á., García-Ramos, J. E., \& Golpe, A. A. (2015). Studying the relationship between economic growth, $\mathrm{CO}_{2}$ emissions, and the environmental Kuznets curve in Venezuela (1980-2025). Renewable and Sustainable Energy Reviews, 41, 602-614. https://doi.org/10.1016/j.rser.2014.08.081

Romero-Ávila, D. (2008). Questioning the empirical basis of the environmental Kuznets curve for CO2: new evidence from a panel stationarity test robust to multiple breaks and crossdependence. Ecological Economics, 64(3), 559-574. https://doi.org/10.1016/j.ecolecon.2007.03.011

Rugani, B., Roviani, D., Hild, P., Schmitt, B., \& Benetto, E. (2014). Ecological deficit and use of natural capital in Luxembourg from 1995 to 2009. Science of the total environment, 468, 292-301.

Ruiz-Agudelo, C. A., Sánchez Pérez, G., Sáenz, J. E., \& Higuera Cárdenas, L. A. (2019). Biodiversity and growth in Colombia, 1995-2015: an approach from the environmental kuznets hypothesis. Journal of Environmental Economics and Policy, 8(1), 17-31.

Saboori, B., Sulaiman, J., \& Mohd, S. (2012). Economic growth and $\mathrm{CO}_{2}$ emissions in Malaysia: a cointegration analysis of the environmental Kuznets curve. Energy Policy, 51, 184-191. https://doi.org/10.1016/j.enpol.2012.08.065

Salvati, L., \& Zitti, M. (2008). Natural resource depletion and the economic performance of local districts: suggestions from a within-country analysis. The International Journal of Sustainable Development \& World Ecology, 15(6), 518-523.

Schaefer, F., Luksch, U., Steinbach, N., Cabeça, J., \& Hanauer, J. (2006). Ecological Footprint and Biocapacity: The world's ability to regenerate resources and absorb waste in a limited time period. Luxembourg: Office for Official Publications of the European Communities.

Selden, T. M., \& Song, D. (1994). Environmental quality and development: is there a Kuznets curve for air pollution emissions?. Journal of Environmental Economics and management, 27(2), 147-162. https://doi.org/10.1006/jeem.1994.1031

Shafik, N., \& Bandyopadhyay, S. (1992). Economic Growth and Environmental Quality: Time-Series and Cross-Country Evidence. Policy Research Working Paper Series, WP. No. 904, Washington, DC: World Bank Publications.

Shahbaz, M., Ozturk, I., Afza, T., \& Ali, A. (2013). Revisiting the environmental Kuznets curve in a global economy. Renewable and Sustainable Energy Reviews, 25, 494-502. https://doi.org/10.1016/j.rser.2013.05.021 
782

783

Shahbaz, M., Sbia, R., Hamdi, H., \& Ozturk, I. (2014). Economic growth, electricity consumption, urbanization and environmental degradation relationship in United Arab Emirates. Ecological Indicators, 45, 622-631. https://doi.org/10.1016/j.ecolind.2014.05.022

Simpson, R., Toman, M., \& Ayres, R. U. (2005). Introduction: The "New Scarcity". In: Simpson, R., Toman, M., \& Ayres, R. U. (Eds.), Scarcity and Growth Revisited Natural Resources and the Environment in the New Millennium, (p 1-32). Washington, DC.: Resources For The Future

Solarin, S.A., Al-Mulali, U., \& Ozturk, I. (2017). Validating the environmental Kuznets curve hypothesis in India and China: The role of hydroelectricity consumption. Renewable and Sustainable Energy Reviews, 80, 1578-1587. https://doi.org/10.1016/j.rser.2017.07.028

Solomon, G. M., Morello-Frosch, R., Zeise, L., \& Faust, J. B. (2016). Cumulative environmental impacts: Science and policy to protect communities. Annual review of public health, 37, 83-96. https://doi.org/10.1146/annurev-publhealth-032315-021807

Stern, D. I. (1998). Progress on the environmental Kuznets curve?. Environment and development economics, 3(2), 173-196.

Stern, D.I., Common, M. S., \& Barbier, E. B. (1996). Economic growth and environmental degradation: the environmental Kuznets curve and sustainable development. World development, 24(7), 11511160. https://doi.org/10.1016/0305-750X(96)00032-0

Tao, S., Zheng, T., \& Lianjun, T. (2008). An empirical test of the environmental Kuznets curve in China: a panel cointegration approach. China Economic Review, 19(3), 381-392. https://doi.org/10.1016/j.chieco.2007.10.001

Tisdell, C. (2000). Free trade, globalisation, and environment and sustainability: major positions and theposition of WTO. Economics, Ecology and the Environment Working Paper 39. Brisbane: The University of Queensland.

Tisdell, C.A. (2001). Globalisation and sustainability: environmental Kuznets curve and the WTO. Ecological Economics, 39(2), 185-196. https://doi.org/10.1016/S0921-8009(01)00234-8

Tisdell, C. A. (2002). The economics of conserving wildlife and natural areas. Cheltenham, UK: Edward Elgar.

Toderoiu, F. (2010). Ecological footprint and biocapacity-Methodology and regional and national dimensions. Agricultural Economics and Rural Development, 7(2), 213-238.

Uddin, G. A., Alam, K., \& Gow, J. (2016). Does ecological footprint impede economic growth? An empirical analysis based on the environmental Kuznets curve hypothesis. Australian Economic Papers, 55(3), 301-316. 
Uddin, G.A., Salahuddin, M., Alam, K., Gow, J., 2017. Ecological footprint and real income: panel data evidence from the 27 highest emitting countries. Ecol. Ind. 77, 166-175.

Wackernagel, M., \& Rees, W.(1996). Our Ecological Footprint, Reducing Human Impact on the Earth. Gabriola Island, Philadelphia: New Society Publishers.

Wackernagel, M., White, S., \& Moran, D. (2004). Using Ecological Footprint accounts: from analysis to applications. International Journal of Environment and Sustainable Development, 3(3-4), 293315.

Wang, Y., Han, R., \& Kubota, J. (2016). Is there an environmental Kuznets curve for $\mathrm{SO}_{2}$ emissions? A semi-parametric panel data analysis for China. Renewable and Sustainable Energy Reviews, 54, 1182-1188. https://doi.org/10.1016/j.rser.2015.10.143

Wang, Y., Kang, L., Wu, X., \& Xiao, Y. (2013). Estimating the environmental Kuznets curve for ecological footprint at the global level: A spatial econometric approach. Ecological indicators, 34, $15-21$.

Wu, P. C., Liu, S. Y., \& Pan, S. C. (2013). Nonlinear bilateral trade balance-fundamentals nexus: A panel smooth transition regression approach. International review of economics \& finance, 27, 318329.

York, R., Rosa, E. A., \& Dietz, T. (2003). Footprints on the earth: The environmental consequences of modernity. American sociological review, 68(2), 279-300.

York, R., Rosa, E. A., \& Dietz, T. (2004). The ecological footprint intensity of national economies. Journal of Industrial Ecology, 8(4), 139-154.

Zoundi, Z. (2017). CO2 emissions, renewable energy and the Environmental Kuznets Curve, a panel cointegration approach. Renewable and Sustainable Energy Reviews, 72, 1067-1075. $\underline{\text { https://doi.org/10.1016/j.rser.2016.10.018 }}$

\section{Appendix}

[Table 8 here]

[Figure 1 here] 
Figures
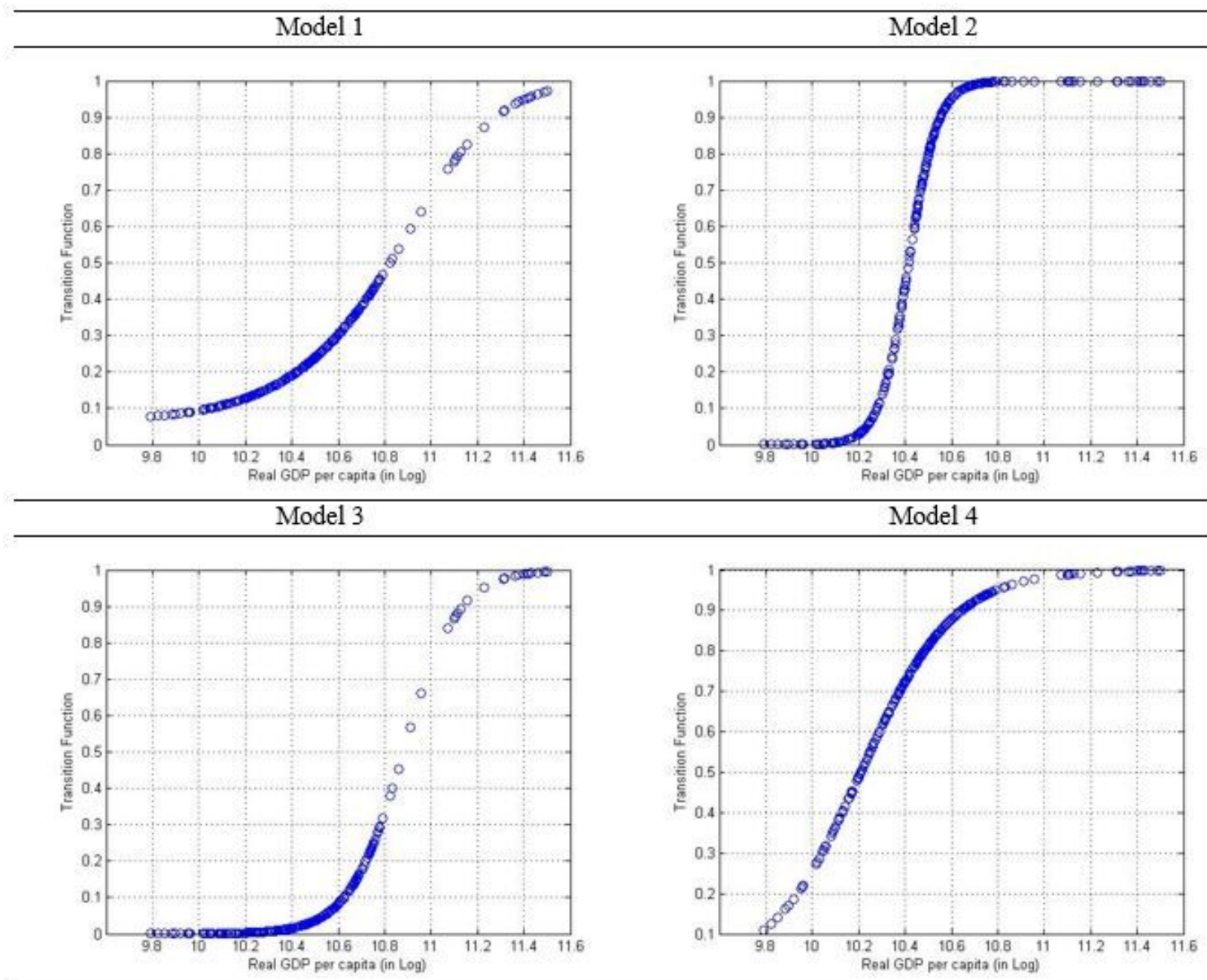

Model 4

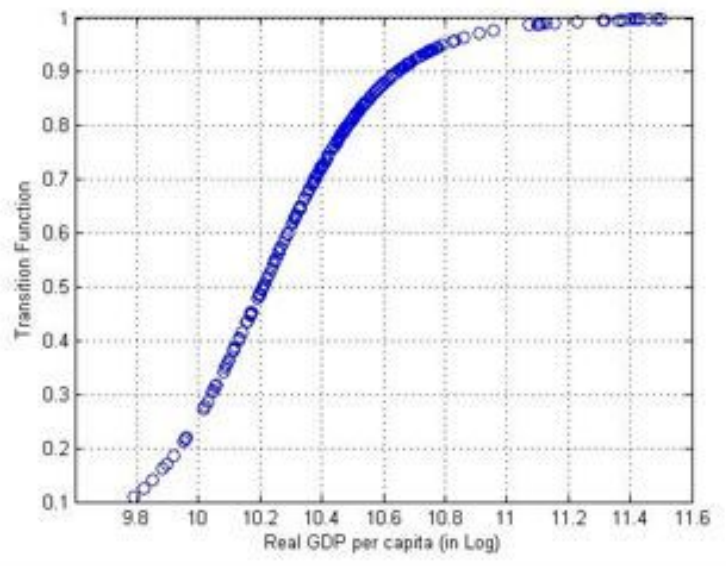

Model 5

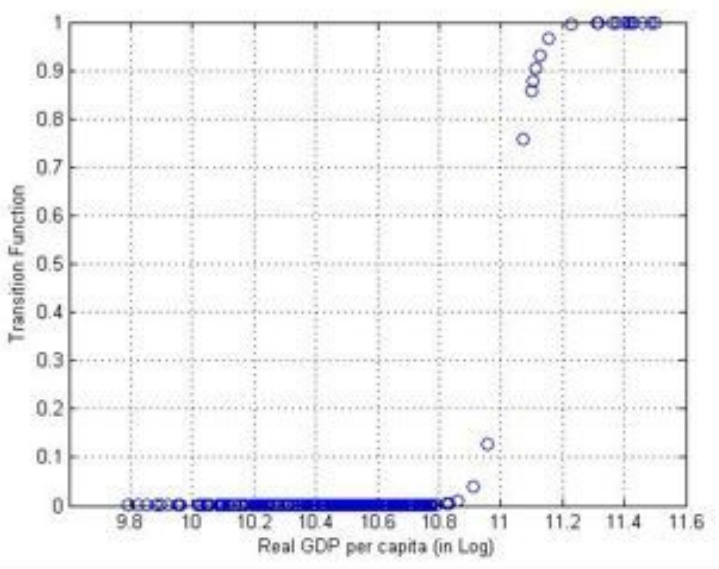

Figure 1

Estimated transition function of the PSTR model against real GDP per capita for all models

\section{Supplementary Files}


This is a list of supplementary files associated with this preprint. Click to download.

- Table5.jpg

- Table6.jpg

- Data.xlsx

- ResponsetoReviewerEditorCommentsandTurnitin.pdf 